\title{
Flu Matrix Protein
}

National Cancer Institute

\section{Source}

National Cancer Institute. Flu Matrix Protein. NCI Thesaurus. Code C18310.

A protein produced by influenza viruses that can link the core material in the virus to the viral envelope. These proteins are involved in both the release of the viral genome into infected cells and the subsequent repackaging of the replicated genome into new virions. 